\title{
The annual cycle of the pituitary-thyroid axis activity in healthy men under prolonged cold air exposure
}

\author{
Evgeny Bojko, Anastasiya Kaneva, Natalya Potolitsyna
}

Department of Environmental and Social Human Physiology, Institute of Physiology Ural Division of Russian Academy of Sciences, Syktyvkar, Russia.

Email: erbojko@physiol.komisc.ru

Received 23 April 2011; revised 10 May 2011; accepted 21 May 2011.

\begin{abstract}
The monthly investigations of military guards ((19.1 \pm 0.9) years, $n=20)$ in northern European region $\left(62^{\circ} \mathrm{N}\right.$ lat.) that daily spent outdoors from 6 to $10 \mathrm{~h}$ were carried out during the year (from November to October). In examined subjects, the serum $\mathrm{FT}_{4}$ levels were high enough during all period of research especially from April till October when the hormone levels exceeded norm. The concentration of serum $\mathrm{FT}_{3}$ was rather stable during the year and corresponded to the normal level. At the same time, the levels of total form of thyroid hormones $\left(\mathrm{TT}_{4}\right.$ and $\left.\mathrm{TT}_{3}\right)$ displaced to lower limit of norm. Thus, staying outdoors of military guards in the North for all the year round is accompanied by activization of thyroid hormones use.
\end{abstract}

Keywords: Thyroid Hormones; Human; Adaptation; North; Cold

\section{INTRODUCTION}

The role of hormones regulating human energy metabolism in cold condition has not been finally clarified. The study of seasonally-related changes of the pituitarythyroid system status in human is interesting so far a long time it was established that hormones of the thyroid gland (TG) play main role in resistance of animal organism to cold [1-3]. It has been shown that single cold-air or crushed ice exposure did not change the levels of serum thyroxin $\left(\mathrm{T}_{4}\right)$ and thyroid-stimulating hormone (TSH) in adult men [4,5]. It has been revealed that the pituitary- thyroid axis in adult human subjects is insensitive to short-time cold exposure that decreased the body core temperature by $0.4^{\circ} \mathrm{C}-0.9^{\circ} \mathrm{C}$ [6]. At the same time, immersion of adult subjects into cold water that decreased tympanic membrane temperature by $1{ }^{\circ} \mathrm{C}$ resulted in twofold increase in the plasma TSH level for 90 min [7]. Repeated 30-min cold-air exposures for 2 months did not lead to changes in the $\mathrm{T}_{4}$ and TSH con- centrations but decreased the level of serum total triiodothyronine $\left(\mathrm{TT}_{3}\right)$ [8]. In another report, the decrease of the serum total $\mathrm{T}_{4}\left(\mathrm{TT}_{4}\right)$ level at repeated cold-water immersion was revealed [9].

The problem of prolonged and seasonal effects of cold is especially important in relation to humans permanently living in the North. The concept proposed in previous studies suggested that the pituitary-TG axis (Pit-TG) is activated during the cold season, which is accompanied by an increase in the levels of serum $\mathrm{TT}_{3}$ and $\mathrm{TT}_{4}[10]$. Later the increased $\mathrm{T}_{3}$ production has been shown in Antarctic winterers [11,12]. At the same time, it was noted in a number of reports that the level of $\mathrm{T}_{4}$ remained unchanged during the year, whereas TSH concentration increased in winter [13]. In northern Finland, the $T_{3}$ concentration in urine was increased in the residents working outdoors from 6 to 10 $\mathrm{h}$ daily but there were no significant changes in the levels of serum $\mathrm{TT}_{3}, \mathrm{TT}_{4}$, free $\mathrm{T}_{4}\left(\mathrm{FT}_{4}\right)$ and the $\mathrm{T}_{4}$ concentration in urine [14]. In winter, the free $\mathrm{T}_{3}\left(\mathrm{FT}_{3}\right)$ level decreased in these subjects, whereas TSH level increased (December), which in authors' opinion might be related to changes in illumination. The authors agree that the thyroid hormones $(\mathrm{TH})$ utilization was increased in cold seasons but recognize that the temperature effect was insignificant (the levels of $\mathrm{TT}_{3}$ and $\mathrm{TT}_{4}$ were unchanged) and the opposite changes of TSH and $\mathrm{FT}_{3}$ were not simultaneous [6]. The decrease of $\mathrm{FT}_{3}$ level during wintering in Antarctica was shown [9]. At the same time, the decrease of $\mathrm{TT}_{3}$ production and the increase of tissue availability of $T_{3}$ during longterm cold exposures were noted $[8,9,12,15]$.

Our research of subjects that worked on Svalbard $\left(78^{\circ}\right.$ $\mathrm{N})$ has shown that the levels of $\mathrm{TT}_{3}$ and $\mathrm{TT}_{4}$ increased twice in the year during sharp change of intensity of the light factor and depended on effect of day duration change rather than on the duration of stay in the North or air temperature [16,17]. Testing with a thyrotropin-releasing hormone (TRH) load in winter showed that rep- 
resentatives of aboriginal Northern populations were characterized by a more pronounced activity of the central part of Pit-TG system as compared to poorly adapted subjects that were also born in the North [18].

Thus, there are still divergences in opinions of the long-term cold-induced changes in the state of the PitTG system. Some discrepancies result from different methodical approaches as the time and the strength of exposure of the external factor in different studies varied wide enough, and the groups were hardly comparable by real conditions of living. It is also mentioned that several studies were conducted in the geographical areas in which seasonal temperature decrease below zero was rare, so that the examined subjects were insufficiently exposed to cold.

The aim of this research was to study the state of the human Pit-TG system in homogeneous group under the conditions of chronic cold exposures during the year.

\section{MATERIALS AND METHODS}

\subsection{Subjects}

Nineteen healthy male Caucasian volunteers (18 - 21 years) were recruited for the present annual study. The subjects were the soldiers (military guards) in Northern European regions of Russia (Syktyvkar, Russia, $62^{\circ} \mathrm{N}$ ) that daily spent outdoors from 6 to $10 \mathrm{~h}$. All the subjects were screened by military physical and physiological manners. The daily routine of the examined subjects was stable throughout the observation period. The subjects passed medical examination and were free of any diseases and disorders possibly affecting their ability to participate in study. The subjects were similar in age and body mass index (BMI). All the recruited persons were not obese $(\mathrm{BMI}<30)$ and have been in the military unit from 4 to 6 months-the time need for acclimations to the North [16]. The study was approved by Institutional Review Boards and each subject signed a written consent prior to participation.

\subsection{Study Protocol}

The study was conducted over a 12 monthly period. The examinations were carried out from Monday to Friday in 3 -th decade of each month. The first examination was conducted in November 2004 and the last in October 2005. The subjects woke up at 06:00 a.m. and visited a nurse's office at 06:30 - 07:30 a.m. Fasting blood samples were obtained from the antecubital vein into vacutainer (Becton Dickinson BP) and physiological measurements were performed. Blood samples were centrifuged and serum was placed into eppendorf microcentrifuge tubes and was stored at $-20^{\circ} \mathrm{C}$ until analyses. Daily mean temperature was obtained from the Province Meteorological Office.

\subsection{Anthropometric Measurements}

Body weight and height were measured using standard medical scale and anthropometer. BMI was determined as the ratio of body weight to height in meters squared $\left(\mathrm{kg} \cdot \mathrm{m}^{-2}\right)$. Waist Circumference was measured to the nearest $0.1 \mathrm{~cm}$ at the umbilicus level and Hip Circumference was measured to the nearest $0.1 \mathrm{~cm}$ at the midpoint between the greater trochanter and the top of the patella.

The percentage of body fat mass was assessed according to the equations of Durnin and Wommersley [19]. For that purpose the skinfold thickness at four sites -biceps, triceps, subscapular and suprailiac - was determined using a Scinfold caliper. The skinfold thickness was measured three times to the nearest $0.2 \mathrm{~mm}$. If result deviated more than $1.0 \mathrm{~mm}$, the three measurements were repeated. Absolute and percent lean body mass (LBN) were calculated from body fat mass (\%) and body weight $(\mathrm{kg})$ :

$$
\begin{aligned}
& \operatorname{LBM}(\%)=[100 \text {-body fat mass }(\%)], \\
& \operatorname{LBM}(\mathrm{kg})=[\text { weight } * \operatorname{LBM}(\%) / 100]
\end{aligned}
$$

\subsection{Biochemical Measurement}

Serum hormones concentration was determined by enzyme-linked assay with a "Power Wave 200" spectrophotometer (Bio-Tek Instruments, USA) using commercial kits according to the manufactures instructions. The reference ranges of normal values and conversion to SI units used for these assays are: $\mathrm{TT}_{4} 64.4-148.0 \mathrm{nmol} / \mathrm{l}$ $(\mathrm{nmol} / 1 \times 0.078=\mu \mathrm{g} / \mathrm{dl}), \mathrm{FT}_{4} 10.3-25.7 \mathrm{pmol} / \mathrm{l}(\mathrm{pmol} / 1$ $\times 0.078=\mathrm{ng} / \mathrm{dl}), \mathrm{TT}_{3} 1.2-3.0 \mathrm{nmol} / \mathrm{l}(\mathrm{nmol} / \mathrm{l} \times 0.651=$ $\mathrm{ng} / \mathrm{ml}), \mathrm{FT}_{3} 2.1-6.5 \mathrm{pmol} / 1(\mathrm{pmol} / 1 \times 0.651=\mathrm{pg} / \mathrm{ml})$, TSH $0.23-3.4 \mu \mathrm{IU} / \mathrm{ml}$ respectively.

The concentration of serum $\mathrm{TT}_{4}$ was measured by commercial kits Randox Laboratories United Kingdom Cat. No TX 2112 with an intraassay coefficient of variance $(\mathrm{CV})$ of $8 \%$.

The concentration of serum $\mathrm{TT}_{3}$ was measured by commercial kits $\mathrm{T}_{3}$-total-IFA-BEST, Vector-Best, Russia, Cat. No X-3954 with an intraassay CV of $8 \%$ and assay detection limit of $0.2 \mathrm{nmol} / 1$.

The concentration of serum $\mathrm{FT}_{3}$ was measured by commercial kits Diagnostic Automation, Inc., Calabasas, CA, USA, Product Code 3148 with an intraassay CV of $5.2 \%$ and assay detection limit of $0.05 \mathrm{pg} / \mathrm{ml}$.

The concentration of serum $\mathrm{FT}_{4}$ was measured by commercial kits Randox Laboratories United Kingdom Cat. No FT 2137 with an intraassay CV of $8 \%$.

The concentration of serum TSH was measured by commercial kits Tiroid-IFA-TSH-1, Alcor Bio, Russia with an intraassay CV $8 \%$ and assay detection limit of $0.05 \mu \mathrm{IU} / \mathrm{ml}$. 


\subsection{Statistical Analysis}

Data were analyzed with Statistica 6.0 (Statsoft, Tulsa, USA). Descriptive statistics was used to calculate mean and standard deviation (SD). Differences in annual dynamics of each parameter were tested by Friedman ANOVA. Where Friedman ANOVA revealed significant effect, a Wilcoxon test with Bonferroni correction for multiple comparisons was used to discern differences between months. Data in the figures and tables are present as mean and SD.

The accepted level of significance was $P<0.05$.

\section{RESULTS}

The outdoor air temperature at 6 a.m. characterizing the weather during the study is presented in Figure 1.

\subsection{Anthropometric Characteristics}

The anthropometric characteristics of the examined subjects are shown in Table 1. No significant changes in subjects' height and body weight were occurred over the observation period.

\subsection{Thyroid Hormones Measurements}

The serum TSH level at the first examination in November was $(1.11 \pm 0.42) \mu \mathrm{IU} / \mathrm{ml}$ and was invariable in December-January (Figure 2). The TSH concentration in the examined group at the first observation varied within normal range from $0.47 \mu \mathrm{IU} / \mathrm{m}$ to $2.09 \mu \mathrm{IU} / \mathrm{m}$. The TSH level was the highest in February when the concentration of this hormone elevated significantly $(P<0.05)$ and

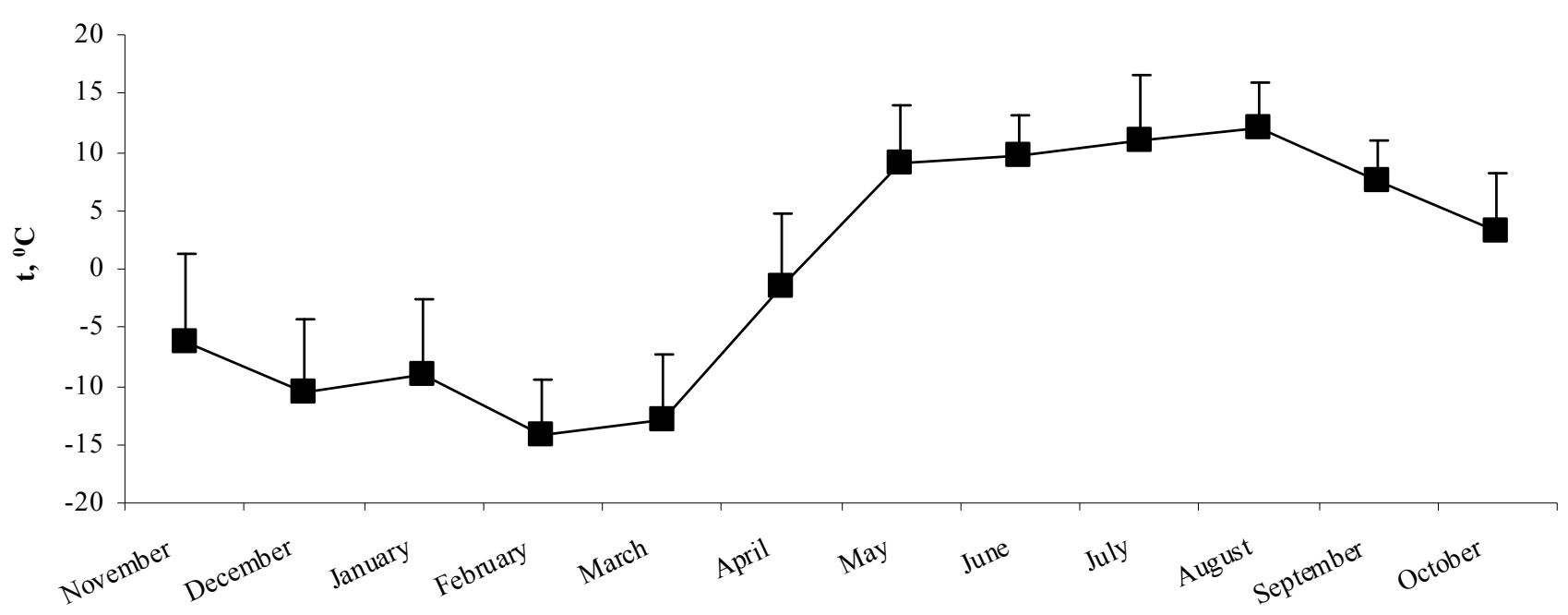

Figure 1. The outdoor air temperature at 6 a.m. during the study.

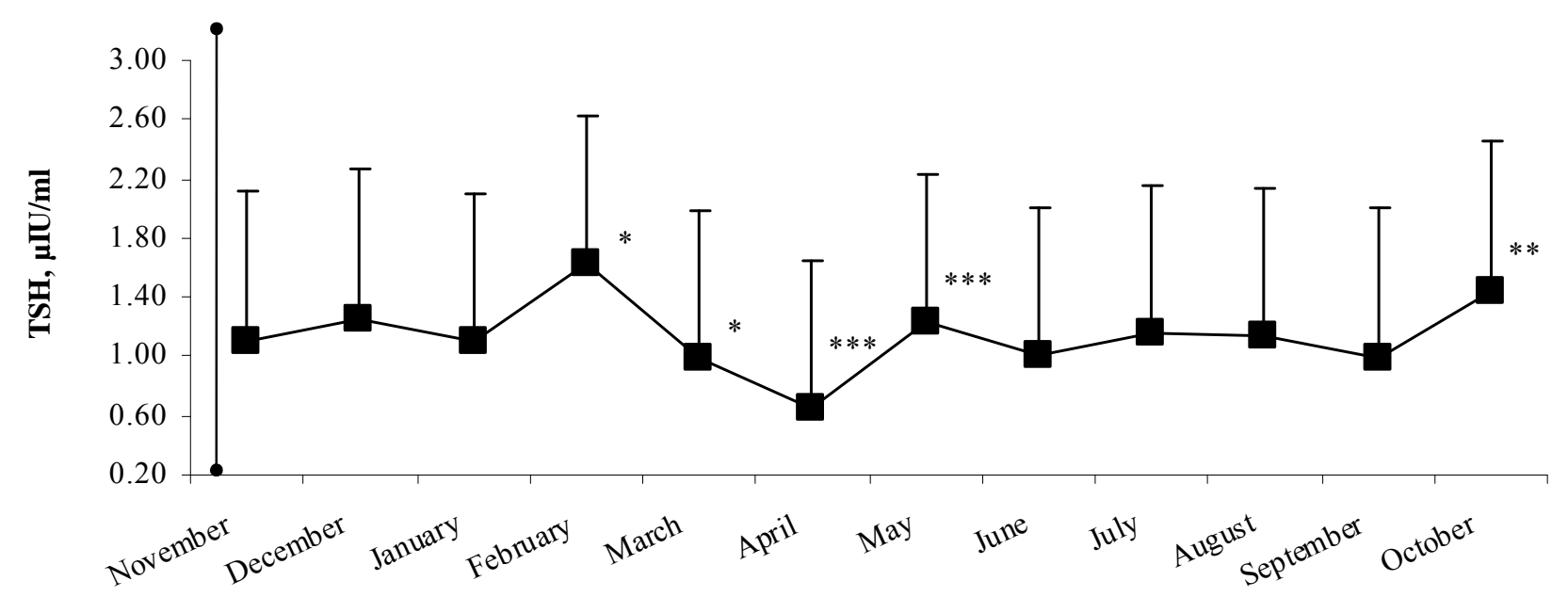

Figure 2. The concentration of TSH in blood serum of northern European male residents during year. The vertical arrow indicates the normative values of TSH $(0.23-3.4 \mu \mathrm{IU} / \mathrm{ml})$. Data are presented as mean $\pm \mathrm{SD}$. $* P<0.05, * * P<0.01,{ }^{* * *} P<0.001$ compared to previous month. 


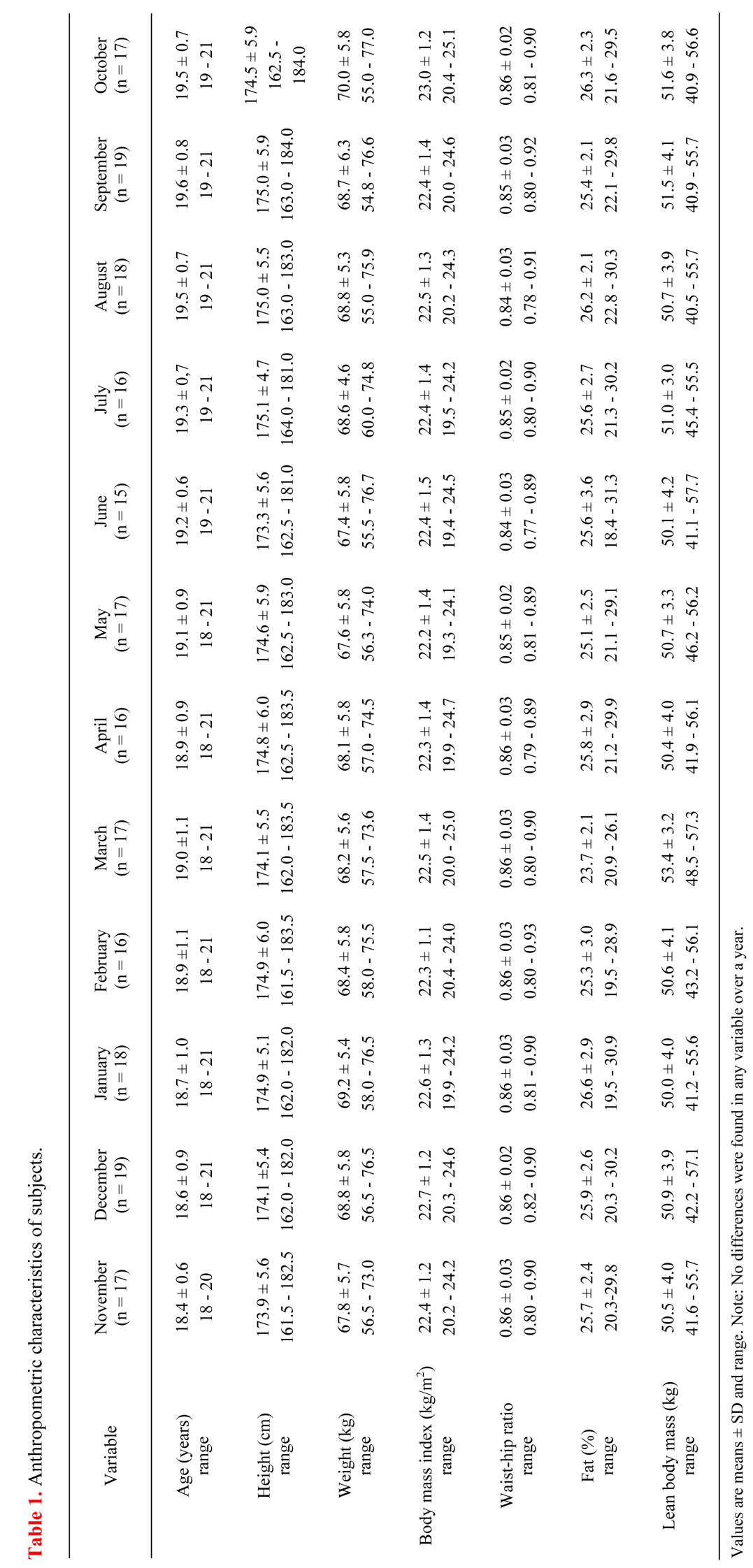


reached $(1.54 \pm 0.85) \mu \mathrm{IU} / \mathrm{ml}$. Next two months the TSH level decreased consecutively and was the lowest in April at $(0.64 \pm 0.18) \mu \mathrm{IU} / \mathrm{m}$ that was significantly lower than during the other months. The next examination performed in May demonstrated an increase in the TSH level to $(1.24 \pm 0.32) \mu \mathrm{IU} / \mathrm{ml}(P<0.001)$. In period of May-September, the TSH concentrations were accorded to levels observed in the subjects in November-January. In October, the TSH level elevated to $(1.45 \pm 0.53) \mu \mathrm{IU} / \mathrm{ml}$ $(P<0.01)$. The range of TSH concentrations in MarchOctober was $0.39-2.61 \mu \mathrm{IU} / \mathrm{m}$.

The $\mathrm{TT}_{3}$ concentration in the subjects at the first examination was $(1.45 \pm 0.69) \mathrm{nmol} / \mathrm{l}$ and ranged within limits of $0.71-2.93 \mathrm{nmol} / \mathrm{l}$. In December, this parameters increased $(P<0.01$, Figure 3$)$ and was the highest for all observations. In February, the $\mathrm{TT}_{3}$ level decreased slightly while that reduced extremely in March and approached the lowest level of $(1.11 \pm 0.49) \mathrm{nmol} / \mathrm{l}$ in April. In May, the $\mathrm{TT}_{3}$ level was returned back to initial values and was stabile up to September. In October, the $\mathrm{TT}_{3}$ concentration decreased to $(1.17 \pm 0.41) \mathrm{nmol} / 1(P<0.01)$.

The $\mathrm{FT}_{3}$ concentration was $(4.46 \pm 1.21) \mathrm{pmol} / 1$ at the first examination in November and $(4.68 \pm 1.07) \mathrm{pmol} / \mathrm{l}$ at the last that in October (Figure 4). The $\mathrm{FT}_{3}$ level fluctuated insignificantly within limits from $4.15 \mathrm{pmol} / 1$ to $4.79 \mathrm{pmol} / \mathrm{l}$ over the year.

The $\mathrm{TT}_{4}$ level in the subjects at the first examination was $(68.2 \pm 17.7) \mathrm{nmol} / \mathrm{l}$ with range of $41.9-89.4 \mathrm{nmol} / \mathrm{l}$ (Figure 5). During the next eleven examinations, the $\mathrm{TT}_{4}$ concentration fluctuated in narrow range from (62.3 $\pm 16.5) \mathrm{nmol} / \mathrm{l}$ in March to $(91.0 \pm 27.64) \mathrm{nmol} / \mathrm{l}$ in $\mathrm{Au}-$ gust. Seasonal dynamics of the $\mathrm{TT}_{4}$ level are given in more detail in Figure 5.

The $\mathrm{FT}_{4}$ level in the subject group in November was $(23.2 \pm 5.4) \mathrm{pmol} / \mathrm{l}$ and ranged from $13.3 \mathrm{pmol} / 1$ to 33.4 $\mathrm{pmol} / \mathrm{l}$ (Figure 6). In November-March, the $\mathrm{FT}_{4}$ level changed slowly. The $\mathrm{FT}_{4}$ concentration in April increased significantly $(P<0.001)$ approaching $(28.9 \pm$ 4.0) $\mathrm{pmol} / \mathrm{l}$, and individual data ranged within limits of 18.6 - $32.0 \mathrm{pmol} / \mathrm{l}$. This $\mathrm{FT}_{4}$ level was higher than normal range proposed by manufacturer to this hormone. The following examinations showed that this elevated level of $\mathrm{FT}_{4}$ remained unchanged in May-October.

\section{DISCUSSION}

The present study demonstrates that long-term influence of cold air results in formation of the adaptive response of the Pit-TG system. Our results indicate that the chronic effect of low temperatures on human organism(guard service) is accompanied by activation of the TH metabolism. It is necessary to noted that this activation caused by the cold influence during most part of the year results in accumulation of $\mathrm{FT}_{3}$ and $\mathrm{FT}_{4}$.

Reed et al. have concluded [20] that in the euthyroid subjects (41 years and older) in condition of prolonged Antarctic residence, the increase in the serum TSH level (approximately $30 \%$ ) was observed without change of the $\mathrm{T}_{4}$ concentration during the winter months. While in the young euthyroid subjects (age 19 to 41 ), there was no circannual pattern in the TSH or $\mathrm{T}_{4}$ levels but the increase in the plasma $T_{3}$ clearance rate and production rate (approximately 30\%) was revealed during winter

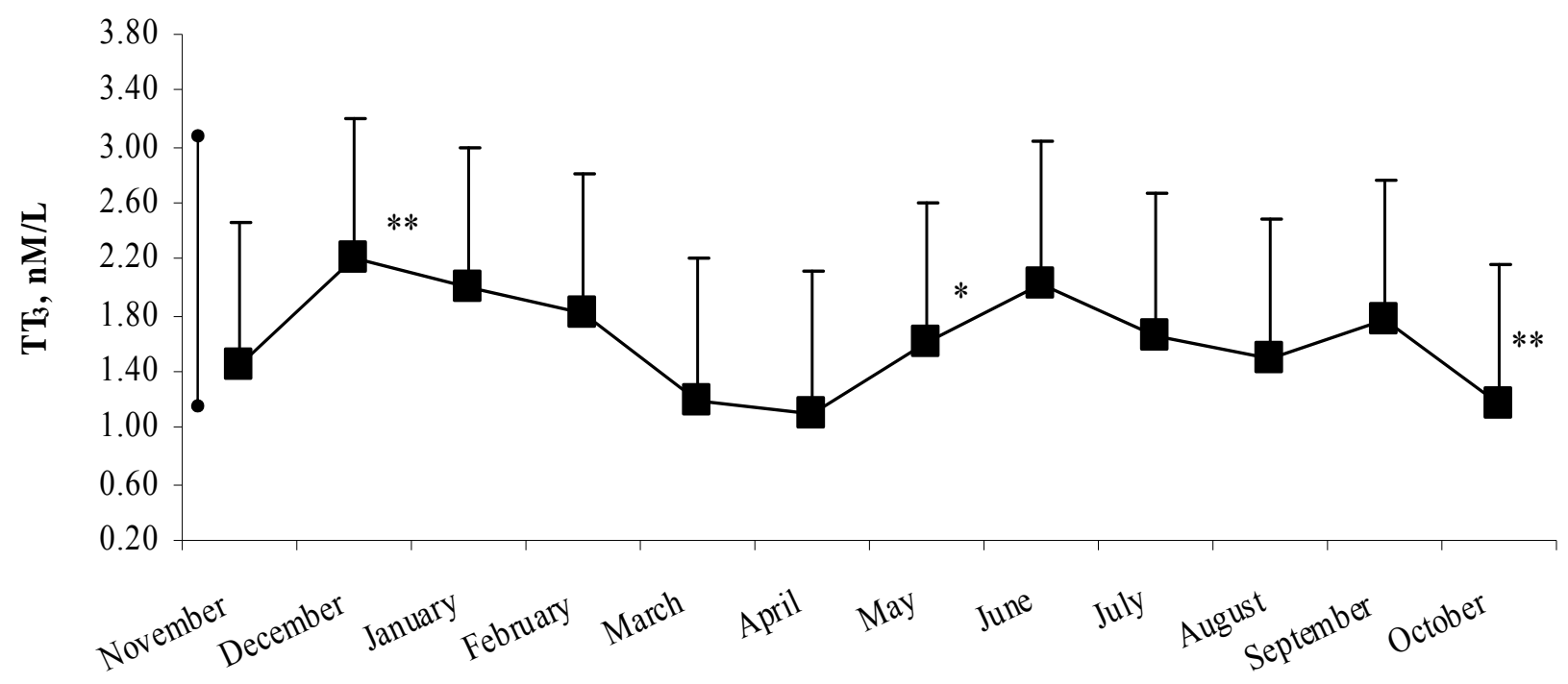

Figure 3. The concentration of $\mathrm{TT}_{3}$ in blood serum of northern European male residents during year. The vertical arrow indicates the normative values of $\mathrm{TT}_{3}(1.2-3.0 \mathrm{nM} / \mathrm{l})$. Data are presented as mean $\pm \mathrm{SD}$. $* P<0.05$, $* * P<0.01$ compared to previous month. 


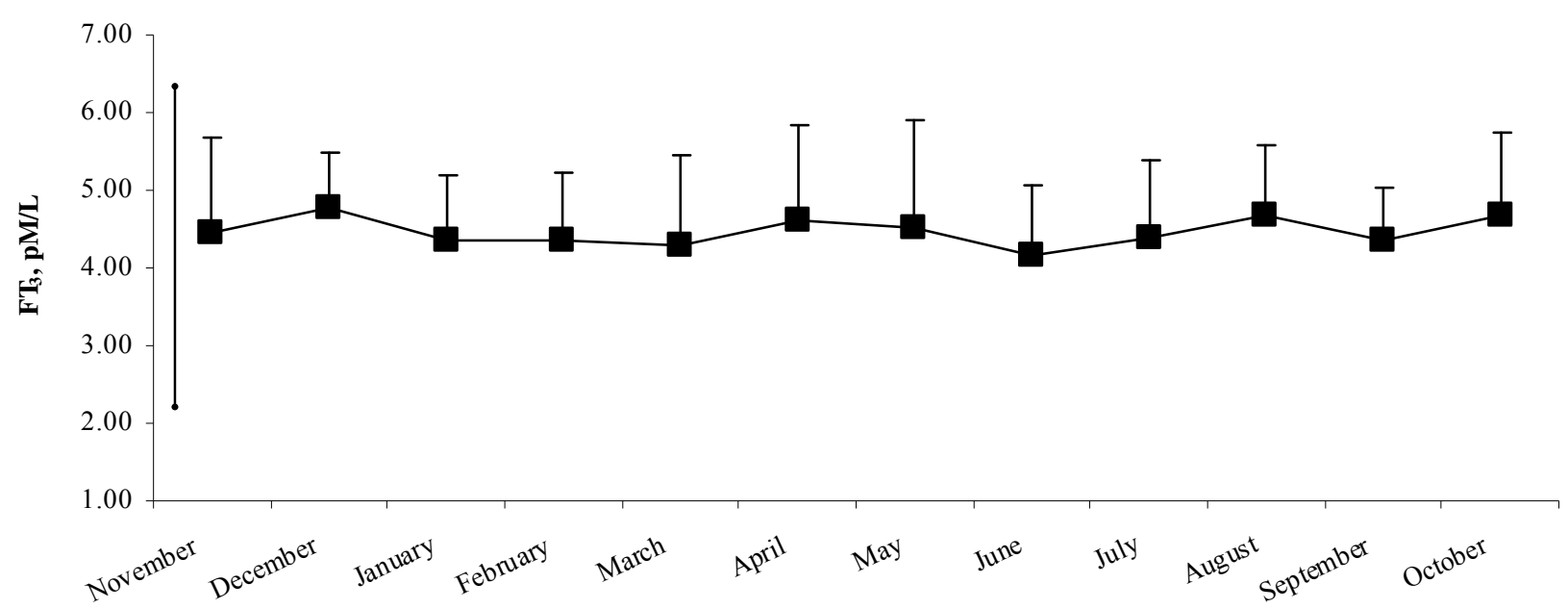

Figure 4. The concentration of $\mathrm{FT}_{3}$ in blood serum of northern European male residents during year. The vertical arrow indicates the normative values of $\mathrm{FT}_{3}(2.1-6.5 \mathrm{pM} / 1)$. Data are presented as mean $\pm \mathrm{SD}$.

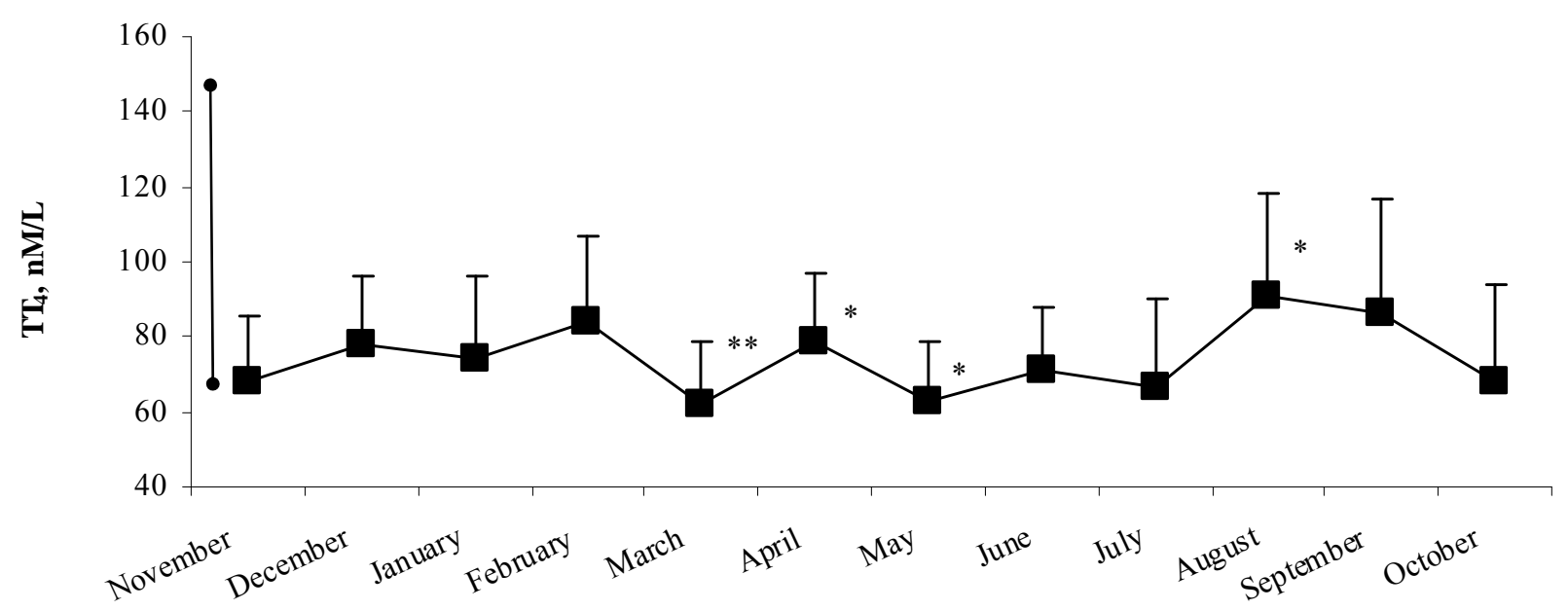

Figure 5. The concentration of $\mathrm{TT}_{4}$ in blood serum of northern European male residents during year. The vertical arrow indicates the normative values of $\mathrm{TT}_{4}(64.4-148 \mathrm{nM} / \mathrm{l})$. Data are presented as mean $\pm \mathrm{SD}$. $* P<0.05$, $* * P<0.01$ compared to previous month.

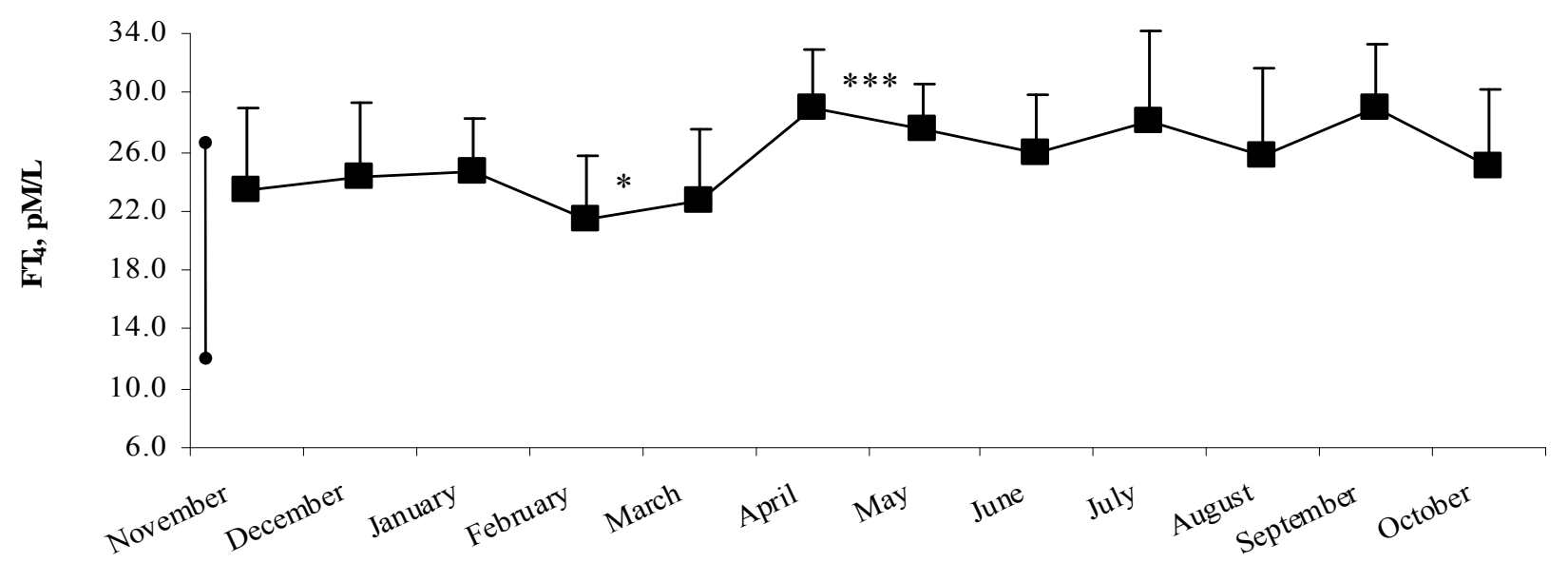

Figure 6. The concentration of $\mathrm{FT}_{4}$ in blood serum of northern European male residents during year. The vertical arrow indicates the normative values of $\mathrm{FT}_{4}(10.3-25.7 \mathrm{pM} / \mathrm{l})$. Data are presented as mean $\pm \mathrm{SD}$. $* P<0.05, * * * P<0.001$ compared to previous month. 
seasons. Young subjects living in Antarctica more than 5 months had a decline in the serum $\mathrm{T}_{3}$ and $\mathrm{T}_{4}$ levels, and the increase in the $\mathrm{T}_{3}$ clearance and production rate. Authors have supposed that the $T_{3}$ kinetic changes have seasonal dependence, and the cold exposure provides this mechanism.

To comment these results, it is to be noted that the researches of inhabitants of the North have shown that the total tension of endocrine system and the impairment of metabolism were found during the first 6 months after arrival in circumpolar regions [16]. Therefore, the examined group in our research consisted of subjects living on the North no less than 6 months.

Data of Indian Antarctic expedition have shown that the levels of total and free fractions of TH varied during wintering. At the end of the Antarctic summer in March, the $\mathrm{TT}_{3}$ concentrations were found to be significantly lower $(P<0.01)$ compared to values recorded before wintering and showed the significant increase $(P<0.05)$ during the Antarctic winter. The $\mathrm{TT}_{3}$ levels from May to December were found to be significantly higher than the March or April values. The plasma $\mathrm{TT}_{4}$ concentrations remained unaltered during wintering in Antarctica. The $\mathrm{FT}_{4}, \mathrm{FT}_{3}$ levels did not show any appreciable change. Though, the $\mathrm{TT}_{3}: \mathrm{TT}_{4}$ ratio tended to decline in March and April suggesting decreased peripheral conversion of $\mathrm{T}_{4}$ to $\mathrm{T}_{3}$ as the possible mechanism for a decline of $\mathrm{TT}_{3}$ level in March. While the monthly studies did not reveal changes in the $\mathrm{FT}_{3}$ and $\mathrm{FT}_{4}$ levels during wintering, the authors have suggested that the serum TH levels during Antarctic wintering were affected by various factors of which the physical activity and the sharp change of day duration were the most significant. The TSH concentrations in March, April, November and December were found to be significantly higher than before wintering [21]. These data testify on our opinion about an important role of ethnic origin of the examined groups.

Thus, our results indicating the increase of use and excretion of $\mathrm{T}_{3}$ in condition of long-term cold exposure correspond to data of Reed et al. [12] and Hassi et al. [14]. At the same time, it is to be noted that our data show that the $\mathrm{TT}_{3}$ and $\mathrm{TT}_{4}$ levels varied insignificantly near lower limit of norm at different temperature regimes during the year. This confirms active conversion of the connected forms of hormones to the active forms at long stay outdoors in the North during the year. Moreover, our results indicate that the produced stimulus did not cause tension in the central component of the Pit-TG system despite of activation of conversion of TH in the free forms. This is shown by the steadily low level of TSH and testifies that the feedback mechanism is inactive.

In research conducted on the similar examined group in Alaska, the essential seasonal variations of the $\mathrm{TH}$ concentration were described in the infantry soldiers during different seasons of the year [22]. The $\mathrm{TT}_{3}$ and $\mathrm{TT}_{4}$ levels were the highest in winter while the $\mathrm{FT}_{3}$ and $\mathrm{FT}_{4}$ levels were the highest in early spring. The correlation between melatonin and $T_{3}$ was revealed in spring (light period of year). The seasonal distinctions were also shown between indigenous and newly arrived people, which may be related not only to cold acclimation but also to day duration. At the same time, this examined group was more heterogeneous in ethnic structure, time spent in the North and professional work than our group, which in the certain degree explains the results received by authors. In another study, the decrease (on 20\%) in the serum $\mathrm{FT}_{3}$ level to the $76^{\text {th }}$ day was shown in young military men in Alaska during three monthly field operations [23].

In our study, the temperature of air in February has gone down below $-15^{\circ} \mathrm{C}$, which was accompanied by slight increase of the TSH level that testified about involving of the central mechanisms of regulation. At the same time, the content of TG peripheral hormones both total and free form was almost unchanged. These two facts, slight increase of the TSH concentration and the stable level of TH in condition of accumulation of free forms of hormones, testify in our opinion that the formed adaptive hormonal profile was still sufficient for compensation of external influence due to accumulation of active forms of hormones.

At the same time, the increase of the TSH level in this period is an adaptive reaction on complex of external influences. In Leppaluoto's opinion [4], the decrease of the body core temperature more than on $1{ }^{\circ} \mathrm{C}$ causes the TSH release. It is possible to suggest that the decrease of air temperature below $-15^{\circ} \mathrm{C}$ and the long stay of our examined group in these conditions are a critical level followed by the reaction of the central component of the Pit-TG system. Thus, the central stimulus for activation of the TH production is formed. However, the activation of the TH formation in the examined subjects at this period was not observed. It is possible to suppose some reasons for explanation of observed phenomenon. Firstly, the decrease of air temperature occurred gradually and the gradient of this influence was possibly insufficient for realization of mechanisms of TH synthesis activation in the TG. Secondly, the cold effects may reduce efficiency of $\mathrm{TH}$ action forming relative resistance to $\mathrm{TH}$ effects in tissues. It is known that actions of TH are determined by intracellular concentration of free hormones. It was demonstrated that the cytosolic $\mathrm{T}_{3}$-binding proteins from human red blood cells rapidly lost activity at low temperature [24]. Moreover, it is necessary to consider that the role of cellular transport in modulating 
intracellular concentration of TH has still been poorly understood but the TH extrusion which can modulate availability and action of TH in mammalian cells has been described [25]. It has been demonstrated that temperature-sensitive TH efflux mechanism that may control cellular TH-content and TH responsiveness presumably by modulating access of $\mathrm{TH}$ to its nuclear receptors is presented in mammalian cells. The altered hormone transport represents one potential explanation for hormone resistance syndromes. So the active hormone efflux constitutes a novel mechanism for physiologic regulation of $\mathrm{TH}$ action that act through the nuclear hormone receptor.

There are data about interrelation of the thyroid function level and the food status. It has been shown that there is significant correlation between the $T_{3}$ and $T_{4}$ levels and the actual food consumption in Evenki, aboriginals of Siberia [26]. The interrelation between the serum $T_{4}$ concentration and the daily consumption of protein and fat was especially strong. The $T_{3}$ level positively correlated with the fatless weight of body and negatively correlated with fatty weight of body in the examined subjects. It has also been noted that there was interrelation between the TH concentration, especially with $\mathrm{T}_{4}$, and body weight in the examined subjects. Authors consider that the received results testify about interrelation between the thyroid function parameters and the basal metabolism level in aboriginals of the North and also reflect importance of account of role of food factor in estimation of basal level of metabolism in northerners.

The study of inhabitants of northern Norway has shown that the TSH level positively correlated with BMI in non-smoking inhabitants whereas there was no this correlation in smokers [27]. In our research, the BMI parameters remained stable during most part of the year. It is possible to note that the significant increase of the air temperature in March-April was accompanied by the decrease in the TSH level to minimal values found for all time of observation. This can confirm supposition that the TSH increase has been caused by the temperature factor. At the same time, the $\mathrm{TT}_{3}$ level decreased to minimal values in March-April, and the $\mathrm{TT}_{4}$ concentration also reduced in March though the level of free forms of hormones was stably high. Thus, the reduction of external cold influences is accompanied by decrease of activity of the central component of the Pit-TG system, which affects in the certain degree secretion of the TG hormones. The mechanisms providing accumulation of free forms of hormones are maintained. Moreover in April, the $\mathrm{FT}_{4}$ concentration exceeded the normal level. When the air temperature in May increased considerably (by $25^{\circ} \mathrm{C}$ concerning March), the TSH level came back to January value (preceding significant increase of the $\mathrm{TSH}$ level). Simultaneously, the $\mathrm{TT}_{3}$ concentration rose insufficiently from the minimal annual levels. At the same time, the increased $\mathrm{FT}_{4}$ level (above the normal values) in the examined subjects was kept up to September. In October, the $\mathrm{FT}_{4}$ parameters returned to norm. It is interesting to note that the hormone profile in October (the last month of the research) was similar to that in February. In this time, the air temperature approached 0 ${ }^{\circ} \mathrm{C}$ that might be a critical value characterizing the termination of the warm period of year. This allows to propose that the mechanism described by us is typical enough for conditions of Arctic region where the environment conditions and the temperature factor alter critically twice during the year. The similar mechanism could be characterized as a certain "medium-term reaction" so far as the accumulation of external factor effect is required for change of functional state of separate components of the Pit-TG system in conditions of aspiration of this system to preservation of stability.

There is a supposition that the cold exposure may enhance the $T_{3}$ production by deiodisation of $T_{4}$ in skeletal muscle via change in muscle fiber type, which could explain the high level of $\mathrm{T}_{4}$ in the examined subjects in summer [2]. Moreover, we should not exclude possibility that the increase of the $\mathrm{FT}_{4}$ level was caused by the fact that the air temperature was low (from $+10^{\circ} \mathrm{C}$ to $+15^{\circ} \mathrm{C}$ ) even in summer. This conditioned the formation of $\mathrm{TH}$ active forms as $\mathrm{FT}_{3}$ level was stably high.

The study has shown that the long-term cold exposures result in activation of use of $\mathrm{TH}$ active forms- $\mathrm{FT}_{3}$ and $\mathrm{FT}_{4}$. The change of action intensity of temperature factor can cause acceleration of conversion of total forms of TH in free forms of that. This process is accompanied by the decrease of levels of connected forms of hormones to lower limit of norm and the accumulation of $\mathrm{FT}_{3}$ and $\mathrm{FT}_{4}$ in blood serum to higher limit of norm. Under these conditions, the central component of the Pit-TG system is not activated keeping constancy of functional state. The activation of the central component of the Pit-TG system is occurred when influence of cold stimulus exceeds a certain limit. This activation is shown by increase of the level of serum TSH. The decrease of cold factor influence intensity results in reduction of tension of the central component of the Pit-TG system and lowing of the serum TSH level.

It is necessary to note specially that mean parameters of the $\mathrm{FT}_{3}$ in our examined group varied from $(4.15 \pm$ $0.91) \mathrm{pmol} / \mathrm{L}$ in June to $(4.79 \pm 0.69) \mathrm{pmol} / \mathrm{L}$ in December. These results completely correspond to data obtained Hassi et al. [14] in the annual research of young outdoor workers from northern Finland. While our data on the $\mathrm{FT}_{4}$ level, which varied from $(21.4 \pm 4.3) \mathrm{pmol} / \mathrm{L}$ to 
$(28.9 \pm 4.0) \mathrm{pmol} / \mathrm{l}$, do not conform to data of Hassi et al. that $\mathrm{FT}_{4}$ level averaged $15 \mathrm{pmol} / \mathrm{L}$. This is probably caused by the fact that determination of both $\mathrm{FT}_{3}$ and $\mathrm{FT}_{4}$ in our and above-mentioned studies was performed by various methods and reagents of different producer therefore there could be diverse reference ranges. Despite in both studies, the levels of free forms of hormones were high and accorded height limit of norm.

In report of Hassi et al. [14], the important fact showing significant elevation of the TSH content during period of the minimal temperatures observed in northern Finland in December has been described. In our research, the TSH level also raised significantly at achievement of the minimally low temperatures that were in conditions of our region in February. Thus, these data also confirm the phenomenon described earlier and allow to explain its origin that was not possible to make in the abovementioned report.

\section{CONCLUSIONS}

Thus, the central and peripheral components of the PitTG system can show certain plasticity in conditions of long-term exposure of cold air. The results of our research allowed to show that adequate selection of the examined groups is important for revealing effect of external long-term stimulus on human organism as it defines obtained results. Our materials allow differentiating the adaptive response of the Pit-TG system as a whole on chronic cold air exposure showing activation of $\mathrm{T}_{3}$ and $\mathrm{T}_{4}$ active forms use at the "moderate" intensity of the external factor action. The central component of the Pit-TG system is activated in conditions of excess of a certain limit-excess of exposure doze. In conditions of the North, this activation of the central mechanisms can not cause mediated reaction from peripheral target organs, and a certain resistance to TSH effect in the TG is observed.

\section{REFERENCES}

[1] Leblond, C.P. and Gross, J. (1943) Effect of thyroidectomy on resistance to low environmental temperature. Endocrinology, 33, 155-160.

doi:10.1210/endo-33-3-155

[2] Laurberg, P., Andersen, S. and Karmisholt, J. (2005) Cold adaptation and thyroid hormone metabolism. Hormone and Metabolic Research, 37, 545-549.

doi:10.1055/s-2005-870420

[3] Silvestri, E., Schiavo, L., Lombardi, A. and Goglia, F. (2005) Thyroid hormones as molecular determinants of thermogenesis. Acta Physiologica Scandinavica, 184, 265 283. doi:10.1111/j.1365-201X.2005.01463.X

[4] Leppaluoto, J., Korhonen, I., Huttunen, P. and Hassi, J. (1988) Serum levels of thyroid and adrenal hormones, testosterone, TSH, LH, GH and prolactin in men after 2-h stay in a cold room. Acta Physiologica Scandinavica, 132, 543-548. doi:10.1111/j.1748-1716.1988.tb08363.x

[5] Thomas, J.R., Ahlers, S.T., House, J.F., Schrot, J., Van Orden, K.F., Winsborough, M.M., Hesslink, R.L.Jr. and Lewis, S.B. (1990) Adrenergic responses to cognitive activity in a cold environment. Journal of Applied Physiology, 68, 962-966.

[6] Leppaluoto, J., Paakonen, T., Korhonen, I. and Hassi, J. (2005) Pituitary and autonomic responses to cold exposures in man. Acta Physiologica Scandinavica, 184, 255264. doi:10.1111/j.1365-201X.2005.01464.X

[7] Leppaluoto, J., Lybeck, H., Virkkunen, P., Partanen, J. and Ranta, T. (1982) Effects of immersion in cold water on the plasma ACTH, GH, LH, and TSH concentrations in man. Circumpolar Health, 81, 601-602.

[8] Hesslink, R.L.Jr., D’Alessandro, M.M., Armstrong, D.W. and Reed, H.L. (1992) Human cold air habituation is independent of thyroxine and thyrotropin. Journal of Applied Physiology, 72, 2134-2139.

[9] Savourey, G., Caravel, J.P., Barnavol, B. and Bittel, J.H. (1994) Thyroid hormone changes in cold air environment after local cold acclimation. Journal of Applied Physiology, 76, 1963-1967.

[10] Nagata, H., Izumiyama, T., Kamata, K., Kono, S. and Yukimura, Y. (1976) An increase of plasma triiodothyronine concentration in man in cold environment. Journal of Clinical Endocrinology and Metabolism, 43, 1153-1156. doi:10.1210/jcem-43-5-1153

[11] Reed, H.L., Fereiro, J.A., Shakir, K.M., Burman, K.D. and O`Brain, J.T. (1988) Pituitary and peripheral hormone responses to T3 administration during Antarctic residence. American Journal of Physiology: Endocrinology and Metabolism, 254, E733-739.

[12] Reed, H.L., Reedy, K.R., Palinkas, L.A., Van Do, N., Finney, N.S., Case, H.S., LeMar, H.J., Wright, J. and Thomas, J. (2001) Impairment in cognitive and exercise performance during prolonced Antarctic residence effect of thyroxine supplementation in the polar triiodthyronine syndrome. Journal of Clinical Endocrinology and Metabolism, 86, 110-116. doi:10.1210/jc.86.1.110

[13] Harrop, J.S., Ashwell, K. and Hopton, M.R. (1985) Circanual and within-individual variation of thyroid function tests in normal subjects. Annals of Clinical Biochemistry, 22, 371-375.

[14] Hassi, J., Sikkila, K., Ruokohen, A. and Leppaluoto, J. (2001) The pituitary-thyroid axis in healthy men living under subarctic climatological conditions. Journal of Endocrinology, 169, 195-203. doi:10.1677/joe.0.1690195

[15] Leppaluoto, J., Sikkila, K. and Hassi, J. (1998) Seasonal variation of serum TSH and thyroid hormones in males living in Subarctic environmental conditions. International Journal of Circumpolar Health, 57, 383-385.

[16] Boiko, E.R. (1996) Realignment of human metabolism in the North. Human Physiology, 22, 496-502.

[17] Bojko, E.R. (1997) Metabolic changes induced by adaptation at 78 degrees North: Svalbard study. International Journal of Circumpolar Health, 56, 134-141.

[18] Boiko, E.R., Bichkaeva, F.A., Tkachev, A.V. and Dogadin, S.A. (1997) Regulation of metabolic reactions in various groups of aboriginal people of Polar Europe: an example of loading test with thyrotropin-releasing hormone. Human 
Physiology, 23, 469-471.

[19] Durnin, J.V. and Wommersley, I. (1974) Body fat assessed from total body density and its estimation from skinfold thickness measurements on 481 men and women aged from 16-72 years. British Journal of Nutrition, 32, 77-97. doi:10.1079/BJN19740060

[20] Reed, H.L. (1995) Circannual changes in thyroid hormone physiology: the role of cold environmental temperatures. Arctic Medical Research, 54, 9-15.

[21] Sawhney, R.C., Malhotra, A.S., Nair, C.S., Bajaj, A.C., Rajan, K.C., Pal, K., Prasad, R. and Basu, M. (1995) Thyroid function during a prolonged stay in Antarctica. European Journal of Applied Physiology and Occupational Physiology, 72, 127-133. doi:10.1007/BF00964127c

[22] Levine, M., Duffy, L., Moore, D.C. and Matej, L.A. (1995) Acclimation of non-indigenous sub-Arctic population: seasonal variation in thyroid function in interior Alaska. Comparative Biochemistry and Physiology. Part A: Comparative Physiology, 111, 209-214. doi:10.1016/0300-9629(95)00016-Z

[23] McCormack, P.D., Thomas, J., Malik, M. and Staschen,
C.M. (1998) Cold stress, reverse T3 and lymphocyte function. Alaska Medicine, 40, 55-62.

[24] Fanjul, A.N. and Farias, R.N. (1993) Molecular interconversion of cold-sensitive cytosolic 3,3',5-tri-iodo-lthyroninebinding proteins from human erythrocytes: effect of cold, heat and $\mathrm{pH}$ treatments. Biochemical Journal, 290, 579582.

[25] Ribeiro, R.C., Cavalieri, R.R., Lomri, N., Rahmaouli, C.M., Baxter, J.D. and Scharschmidt, B.F. (1996) Thyroid hormone export regulates cellular hormone content and response. Journal of Biological Chemistry, 271, 1714717151. doi:10.1074/jbc.271.29.17147

[26] Leonard, W.R., Galloway, V.A., Ivakine, E., Osipova, L. and Kazakovtseva, M. (1999) Nutrition, thyroid function and basal metabolism of the Evenki of central Siberia. International Journal of Circumpolar Health, 58, 281-295.

[27] Nyrnes, A., Jorde, R. and Sundfjord, J. (2006) Serum TSH is possibly associated with BMI. International Journal of Obesity, 30, 100-105. doi:10.1038/sj.ijo.0803112 